\title{
An Interest Rate Commission Agent Banking System
}

\section{Ameha Tefera Tessema ${ }^{1 *}$ and Kruger $\mathrm{JW}^{2}$}

${ }^{1}$ Doctor of Business Leadership, Graduate School of Business Leadership, University of South Africa, South Africa

${ }^{2}$ Professor, Department of Corporate Finance, University of South Africa, South Africa

\begin{abstract}
The bank's toxic or nonperforming asset or contagion and liquidity problems that can prone any time the banking business unsolved for last decades. To solve these problems banks were adopted several models even though each of banking business models was a catalyst for financial crises. However, these problems can be solved applying an interest rate commission agent banking system which is a system to be adopted by bank to be an agent for investors' loan funding to entrepreneurs by getting the fund seller and buyer agreement to administer the loan after disbursement, by retaining reasonable interest rate commission from the agreed investor's loan funding credit price. The bank as an agent administer investor's loan funding to entrepreneur up to loan settlement by collecting an agreed interest rate commission. An interest rate commission agent banking system can directly increase profitability of the bank since no saving interest rate can be paid on the loan disbursed amount from an investor account. Since increasing deposit interest rate increases deposit mobilization, Applying discrete market interest rate incentive also expected to increases the deposit mobilization. In same manner increasing the credit price will increase the demand of the investors to provide loan funding which in turn increase the bank's loan mobilization.
\end{abstract}

Keywords: Bank toxic asset; Contagions; Investor loan funding; Discrete interest rate; Interest rate commission; Agent banking; Liquidity problem; Banking model

\section{Introduction}

Banking sector does have a bloody relationship with all sectors in the economy and strengthening of banking system in a country would lead to develop the country economy otherwise the banking crises can affect the economy as a wholes. Since all sector pass through the banking service to reach their financial target, the banking crises which arise from credit crunch can affect all sector in the financial system. The bank toxic asset is the only major sources of financial crises that created by credit crunch lead the bank to prone lending and consequences later retarding the country economy. Since many sub-Saharan Africa are less integrated into global market, the global financial crises will affect the living standard of the countries and expected to lead to higher level of global poverty [1]. By managing credit risk, liquidity risk and interest rate risk banks could increase their competitive advantage which in turn lead then to increase their shareholder value and this could also keep safe the counterparty risk should the bank continue managing its risks which could arise in operation [2].

The bank risk management feasibility study is less integrated with the borrower's project failures when the feasible project comes into reality. Uncertainty of the borrowers' business project outcome that led the loan repayment to be uncertain led banks failure common in every country. To mitigate risk bank secure loan against collateral which help to cover the remaining loan amount by selling the pledge property publicly, however, the collateral foreclosed may not cover the remaining loan balance which may be latter repaid by searching attachable properties in the name of the principal borrower. If the remaining loan balance uncovered by selling the properties of the borrowers, the toxic asset remained in the balance sheet exposed the bank to fail ultimately and thereby the bank suffer from capital erosion and deposit run by depositors [3]. In traditional banking activities after loan disbursement to borrower, the loan repayment collection process became too long which also lead the bank to liquidity problem in short run.

The main cause of bank's credit crunch and liquidity problems is that bank holds the customer fund as its own asset in balance sheet. The bank buying and selling of fund to get excessive revenue from loan has deprived the right of customer to get reasonable benefit from their deposited fund at bank. Because of these facts, bank unable to control dynamic credit and liquidity risk from time to time. In order to solve these problems banks are shifting from traditional banking activities to non-traditional banking activities to get noninterest income to avoid the risk related with credit crunch [4]. As a result, the interaction of demand and supply of money created a credit risk transferring market at which the bank exercised transferring of credit risk from originating and holding on balance sheet to originating and disbursing to investors in the market even though this has not yet solved the bank credit crunch and liquidity problems [5].

However, an interest rate commission agent banking business model can bring mutual benefit for investors, entrepreneur, depositors and the bank by establishing lucrative interest rate directly to fund providers and the bank to satisfy the demand of the entrepreneur. Since the bank administer the investor loan funding having collected the interest rate commission from investors credit price, the bank balance sheet doesn't affect by the balance sheet risks such as credit risk, liquidity risk, market risk and operational risk. And also, the bank mobilizes more stable saving by paying discrete interest rate incentive. Since the model can work with other banking business model according to the organization's incentive, structure, culture and skill of the employees, it can protect the bank and fund provider from windfall and permanent banking risks for which other business models failed to do so. Since the bank gets uninterrupted commission income without holding the

*Corresponding author: Ameha Tefera Tessema, Doctor of Business Leadership, Graduate School of Business Leadership, University of South Africa, South Africa, Tel: 251-912365549; E-mail: ambet22002@yahoo.com

Received August 04, 2015; Accepted October 28, 2015; Published November 04, 2015

Citation: Tessema AT, Kruger JW (2015) An Interest Rate Commission Agent Banking System. J Glob Econ 3: 160. doi:10.4172/2375-4389.1000160

Copyright: (c) 2015 Tessema AT, et al. This is an open-access article distributed under the terms of the Creative Commons Attribution License, which permits unrestricted use, distribution, and reproduction in any medium, provided the original author and source are credited. 
depositors' fund as its own asset in balance sheet and without paying funding cost to an investor's loan funding, the bank's sustainability in market can be kept more by applying an interest rate commission agent banking system.

The organization of the paper designed as follows: section 4 discusses how bank get relief from bank toxic or non-performing asset or contagion and liquidity problems, section 5 discuss how banking problems could be solved being bank as financier and commission agent for investor loan funding, section 6 discuss how commission agent bank keep bank's sustainability in the market, section 7 discusses the determinants of an interest rate commission agent bank, section 8 discusses how to transfer credit risk to investor and entrepreneur to solve liquidity and credit risk and Finally section 9 puts conclusion remark.

\section{Relieving Bank from Toxic Asset, Nonperforming Asset or Contagion}

The bank faces solvency problem as a result of holding toxic or impaired asset which can be the source of financial crises [6]. As the toxic asset of the bank increases the bank profitability will decrease. Since toxic asset has an inverse relationship with capital, the sensitivity to change capital of the bank will positively affect the bank's profitability. In order to refill the liquidity gap, banks lend fund to similar financial institution to develop interbank market without considering their counterparty losses and credit worthiness that can expose to bank toxic asset. Since contagion is a financial institution disease that can be transfer to countries across border can be created by lending and borrowing loan among financial institutions without having studied counterparty risks [7]. Proper management of the bank loan and deposit from conception to an end in a compatible manner will lead to achieving the profit maximization and reduces bank toxic asset as aimed at earlier [8].

In traditional banking theory bank collect deposit from customer to disburse it to entrepreneur to get lucrative interest rate by holding the disbursed loan to entrepreneur as its own asset in balance sheet and thereby it takes higher credit risk and liquidity risk. The source of bank credit crunch is the bank lending and borrowing using client fund having born the risk associated with it. To solve these banking problems bank shall to work as financier and commission agent bank as the market permits to avoid bank toxic asset and liquidity problem. Applying an interest rate commission agent banking system increases the profitability of the bank by avoiding bank toxic asset and increasing bank solvency by managing the customer fund for customer benefit and mobilizing deposit by incentivizing the customer deposit an interest rate.

An interest rate commission agent bank is a system to be adopted by bank in managing the investor loan funding to an entrepreneur by collecting reasonable interest rate commission from investor credit price. So the bank as an agent holds the disbursed loan and investor deposit on liability side of the balance sheet and the net effect of the loan transaction on the balance sheet will be nil. Since the agent bank work for mutual benefit of the bank, investor and entrepreneur by transferring credit and liquidity risk to investor and entrepreneurs, the bank toxic asset will be alleviated.

So that banks can avoid bank toxic or non-performing asset or contagion and liquidity problem permanently by transferring credit risk to an investor and entrepreneur and by mobilizing loan and deposit using investor's loan funding and discrete market interest rate incentive for deposit mobilization respectively. The selected commission agent bank can disburse loan to entrepreneur directly using stable fund if the individual depositor's interest is to get discrete market interest rate.

\section{The Bank Role as Financier and Commission Agent Bank}

In administration the investor loan funding to an entrepreneur the bank will collect an interest rate commission and the excesses above this interest rate commission will be credited into investor's account at same bank. It is the basic fact that an interest rate can create a link among investor's loan funding, deposit mobilization, and entrepreneur. In conventional banking the loan interest rate depends only on the past trend of the deposit interest rate [9]. Whereas in the interest rate commission agent banking system the determination of the loan and deposit interest rate based on the past trend of both loan and deposit interest rate. An interest rate commission agent banking system bases on the notion that as interest rate increases the demand of fund supplier also increases [10,11]. As the credit price increase the demand of investor to supply fund for loan either in group or in single having the bank as an agent in administrating the loan funding after disbursement increases. By an interest rate commission agent banking system the loan granted by an investor to an entrepreneur could never be hold as an asset on the bank's balance sheet and the loan disbursement effect by transferring the loanable fund from an investor account to an entrepreneur account on the liability side of the bank's balance sheet.

An interest rate commission agent bank administers the investor loan funding to entrepreneur by collecting an agreed interest rate commission from investor loan funding credit price. The agent bank commission can be fixed percentage or as per the agreement between the fund provider and the agent bank depending on the central bank rules and regulations If the fund provider wishes to receive discrete market interest rate incentive, the bank can use the fund for own investment by mobilizing deposit applying discrete market interest rate incentive on the depositors account. If the fund provider wishes to receive credit price in between, the bank will start to calculate the interest rate commission on the loan disbursed amount by ceasing calculating deposit interest rate on the fund disbursed to entrepreneur and the fund provider displaces to receive credit price in terms of discrete market deposit interest rate. Managing loan and deposit as financier and agent bank will keep benefiting the majority of unbanked and banked population in the society.

\section{Sustainability of an Interest Rate Commission Agent Bank}

An interest rate commission agent banking system can directly increase profitability of the bank since no saving interest rate can be paid on the loan disbursed amount from an investor account. As deposit interest rate increases the bank deposit mobilization will increase. Since increasing deposit interest rate increases deposit mobilization, applying discrete market interest rate incentive also expected to increases the deposit mobilization. As the credit price increases, investor loan funding expected to increase which in turn increase the bank's loan mobilization. Since an interest rate commission agent banking system totally transfer the bank credit risk to an investor and entrepreneur, and increases liquidity by incentivizing interest rate on deposit account, the bank never expected to meet credit risk, liquidity risk and interest rate risk.

In administrating the investor loan funding to entrepreneur, 
interest rate commission agent bank receives non-volatile and uninterrupted interest rate commission from investor loan funding credit price by ceasing calculating interest rate on the fund disbursed amount, the bank can maximize profitability by alleviating funding cost. The bank as an interest rate commission agent bank can alleviate banking credit risk and liquidity by transferring credit risk to investor and entrepreneur, and mobilizing deposit incentivizing interest rate on the customer deposit account respectively. So that, the bank sustainability in the market will reliable and viable.

\section{Determination of an Interest Rate commission of Agent Bank}

Bank as a financial institution accepts money for deposit to lend the deposited amount to an entrepreneur. Since the deposit at bank does have uni-directional with loan, in traditional banking the determination of loan interest rate bases on the preceding trend of deposit interest rate [12]. To mobilize deposit, bank pays low interest rate into depositor's accounts for loan disbursement to entrepreneurs to gather loan interest rate more than twice of the interest paid into depositors' account [13]. Disbursing fund to entrepreneur holding the disbursed loan as the bank's asset led the banking business to be affected by credit risk, liquidity risk and interest rate risk.

To solve banking risks, several credit risk transferring bank's business models adopted by banks earlier were a catalyst for financial crises for more than a decade [5,14-18]. Because of this fact, money depositors at bank have not fully exercised their right to get full benefit of their money deposited rather than receiving unreasonable deposit interest rate that forced them to join informal market [19]. The bank deposit mobilization affected by informal financial system where major of currency circulate out of bank to avoid government tax and to use money laundering $[20,21]$. So by applying discrete market interest rate at deposit account using an interest rate commission agent banking system enable to mobilize more stable saving from informal sector [13].

To increase an interest rate commission of the agent bank benefiting investors credit price as per the rules and regulation permit by central bank of the country will increase the demand of investors to supply more loanable fund sustainably. Since an interest rate commission agent banking system administer the investor loan funding to entrepreneur, benefiting investor credit price will lead all banked and unbanked society to get more into banking system. Though the determination of loan interest rate in traditional banking based on the preceding trend of the deposit interest rate, credit price of the investor loan funding determined by an interest rate commission agent bank based on the interaction of demand and supply of loan in the market having kept the rules and regulation of the central bank of a country. If the fund provider target to receive credit price in the long run but wish to receive now discrete market interest rate incentive, the agent bank use the fund for own investment by paying discrete market interest rate incentive into depositors account which later cease calculating interest rate on deposit account when the fund provider request in between the bank to lend the fund to entrepreneur. After the fund provider and the bank have agreed, the bank become an agent for inventor loan funding by receiving interest rate commission in terms of credit price which then after will be paid into investor account.

So investor loan funding, deposit mobilization incentivizing interest rate on depositors account, the credit price of the investor loan funding, the demand and supply of loan in the market, and informal financial sectors are the determinant of an agent bank's interest rate commission.

\section{Transferring Credit Risk to Investor and Entrepreneur to Solve Liquidity and Credit Risk}

In order to keep mutual benefit of the bank, investor/depositor and entrepreneur using an interest rate commission agent banking system model to mitigate banking risks, banks shall consider separation of service selling and buying money to sell in order to maximize profit [22]. In traditional banking activities, banks are limited to buy deposit from clients to sell it to an entrepreneur at the credit price, whereas, in non-traditional banking activities banks are involved in selling their service to their client according to terms and tariff of the bank. Though interest income is non-volatile than non-interest income, the systematic risk associated with non-interest income is higher than interest income [23].

However, the agent bank that collects interest rate commission income from investor's loan funding credit price by administrating investor loan funding to an entrepreneur is non-volatile and continuous up to loan settlement. Unless the bank use the investor fund for its own investment purpose the agent bank cease calculating deposit interest expense on the fund disbursed amount from an investor's deposit account. Since an interest rate commission agent banking system model transfer credit risk to investor and entrepreneur and collects non-volatile interest rate commission from an investor loan funding credit price, the sustainability of the bank in the market will be more viable and reliable than those bank applied other business models in same market.

Bank as an agent administers the investor's loan funding to an entrepreneur based on the central bank's rules and regulation as the terms and conditions permits between an investor, entrepreneur and the bank. Since the system gives full right benefit to an investor and an entrepreneur, they will be principal motivators of the bank. Maintaining mutual benefit of the bank, investor and entrepreneurs creates an opportunity for growth of an individual/organ economy in the society and thereby lead to develop the country economy as whole.

An interest rate commission agent banking system does not hold the customer deposit as its own asset in the balance sheet, the transaction of loan disbursement and collection will be completed on the liability side of the balance sheet and thereby the bank transfer credit risk to investor and entrepreneur by managing loan for an investor with or without pledging collateral according to the agreement between an investor and entrepreneur.

\section{Conclusion}

Applying an interest rate commission agent banking system maintains mutual benefit of an investor, entrepreneur and the bank by attracting unbanked and more banked society into banking system. It also increases the investment by narrowing the gap between informal and formal financial market. Banks that apply an interest rate commission agent banking system will maximize their profitability and thereby increase their sustainability in the market. Since the model nil the financial cost of the fund disbursed, the bank simply maximizes profitability by collecting an interest rate commission continuously up to the settlement of the loan. The bank as an agent administer the loan disbursed rather than holding the loan as an asset in its balance sheet and hence the bank could never be affected by credit risk. To increase liquidity the bank can mobilize deposit by applying discrete interest rate incentive on the depositor's account. So that, the bank can directly finance loan to an entrepreneur to collect credit price. Therefore the bank can work as an agent as well as direct loan financier. 
So investor loan funding, deposit mobilization incentivizing interest rate on depositors account, the credit price of the investor loan funding, the demand and supply of loan in the market, and informal financial sectors are the determinant of an agent bank's interest rate commission.

To avoid banking credit crunch and liquidity problem the agent bank can transfer credit risk to investor and entrepreneur and mobilize deposit by incentivizing interest rate on the customer deposit respectively. An investor can provide fund to the agent bank either to receive credit price now by disbursing loan to an entrepreneur or a discrete market interest rate incentive. If the fund provider wishes to receive discrete interest rate incentive on the fund deposited, the bank will disburse it to entrepreneur to get credit price but if the fund provider request the bank in between to receive credit price instead of deposit interest rate on the fund already disbursed to an entrepreneur, the bank immediately cease calculating deposit interest rate on the fund disbursed amount and receives interest rate commission in terms of credit price by administrating the loan on behalf of the investor.

Generally applying an interest rate commission agent banking system can enhance investment, the fund provider and borrower will be the principal promoter of the agent bank rather than the bank get into society advertising its product with high cost, money laundering and informal financial market will be alleviated, banking problems such as bank toxic asset or contagion and liquidity problems will be alleviated.

\section{References}

1. John PG, Emmett CW (2012) The global Financial Crisis: Policies and implications. Nova Science Publishers, New York.

2. Stulz, Rene (2008) Risk Management Failures: What Are They and When Do They Happen?. Journal of Applied Corporate Finance 20: 58-67.

3. Basu S (2003) Why Do Banks Fail?. International review of Applied Economics 17: $1-19$

4. Damankah BS, Anku-Tsede O, Amankwaa A (2014) Analysis of Non-Interest Income of commercial Banks in Ghana. International Journal of Academic Research in Accounting and Management Sciences 4: 263-271.

5. Bruno B, Bedendo M (2013) Credit risk transfer in U.S. commercial banks: What changed during the 2007-2009 Crisis? Journal of Banking Finance 36: 3260-3273.

6. Boudghene Y, Maes S (2012) Relieving Banks from Toxic or Impaired Assets: The EU State Aid Policy Framework. Journal of European Competition Law and Practice.

7. Memmel C, Sachs A, Stein I (2012) Contagion In the Interbank Market with
Stochastic Loss Given Default. International Journal of Central Banking 8 : 177-206.

8. Davydenko A (2010) Determinant of Bank Profitability in Ukraine. Undergraduate Economic Review 7: 1-30.

9. Kaymaz O, Kaymaz O (2011) Using deposit interest rates In Setting Loan Interest Rates: Evidence from Tukey. The International Journal of Business and Finance Research 5: 45-53.

10. Siyanbola TT, Adedeji SB (2012) Effect of Interest Rate Deregulations on Banks deposits Mobilization in Nigeria. International Journal of Marketing and Technology 2: 194-203.

11. Mashamba T, Magweva R, Gumbo LC (2014) Analysing The Relationship between Banks Deposit Interest Rate and Deposit Mobilization: Empirical evidence From Zimbabwean commercial Banks (1980-2006). Journal of Business and Management 6: 64-75.

12. Hossain B, Bhuiyan AH, Rahman H (2013) Deposit Behavior and Its Impact on Loan: A case Study on Rajshahi Krishi Unnayan Bank (RAKUB), Bangladesh. Journal of Economic Cooperation and Development 34: 47-60.

13. Chakazamba L, Matanda E, Dube H (2013) An Investigation into the Strategies Zimbabwean Commercial Banks Can Employ to Mobilize Savings from the Informal Sector. Journal of International Academic Research for Multidisciplinary 1: 10-20.

14. Blommestein HJ, Keskinler A, Lucas C (2011) Outlook for the Securitization Market. OECD Journal: Financial Market Trends 1: 1-18.

15. Zuckerman AM (2011) Securitization Reform: A coasean Cost Analysis. Harvard Business Law Review 1: 303-317.

16. Baicu CG, State O (2012) Banking Model under the Impact of the PostCrisis Organizational Changes Apt to Confer Sustainable Financial StabilityRomanian Experience. The Amfiteatru Economic 32: 436-450.

17. Mandel BH, Morgan D, Wei C (2012) The Role of Bank Credit Enhancements in Securitization. FRBNY Economic Policy Review 18: 35-46.

18. Young T, McCord L, Crawford PJ (2010) Credit Default Swaps: The Good, The bad and The Ugly. Journal of Business and Economic Research 8: 29-35.

19. Simon-oak OO, Jolaosho OM. (2013) Real Interest rate and Savings Mobilization in Nigeria. International Journal of Development and Economic Sustainability 1: 28-40.

20. Perazzi JR, Merli GO, Paredes LC (2010) The Size of Informal Economy In Venezuela. El Norte-Finnish Of Latin American Studies 5: 1-12.

21. Ogbuabor JE, Malaolu VA (2013) Size and Causes of the informal Sector of the Nigerian Economy: Evidence from Error Correcting Mimic Models. Journal of Economics and Sustainable Development 4: 85-104.

22. Wen S, Yu J (2013) Banking Stability, Market Structure and Financial System in Emerging Countries. Journal of applied finance and Banking 3: 1-13.

23. Jaffar K, Mabwe K, Webb R (2014) Changing Bank Income Structure: Evidence from Large UK banks?. Asian Journal of Finance \& Accounting 6: 195-215. 